\title{
UDC 027.7:004.08
}

HOVORUKHA V. B.

Department “Computational Mathematics and Mathematical Cybernetics”, Oles Honchar Dnipro National University (Dnipro, Ukraine), e-mail govorukhavb@gmail.com, ORCID 0000-00020936-9272

SEMENOVA Larysa A.

Scientific and Technical Library, Dnipro National University of Railway Transport named after Academician V. Lazaryan (Dnipro, Ukraine), e-mail loly.sem2964@gmail.com

SEMENOVA Liudmyla A.

Scientific and Technical Library, Dnipro National University of Railway Transport named after Academician V. Lazaryan (Dnipro, Ukraine), e-mail mila.sem29@gmail.com

\section{NETWORKING INFORMATION TECHNOLOGIES AS A METHOD INNOVATIVE CHANGES IN ACADEMIC LIBRARIES}

\begin{abstract}
Objective. The article examined at current global trends to require significant changes of the educational and library infrastructure. The analysis of these tendencies and of the current state of development of the educational and library sphere gave an opportunity to understand to the implementation of network technologies can affect to the activities of academic institutions. Methods. At the present stage, the popularity of distance technologies is increasing because they are best able to meet the new needs of modern users of library networks. The authors identified the factors of popularity and scope of networking technologies and investigated their influence on various aspects of the practical activity of university libraries. Results. Practical experience of the Scientific and Technical Library of DNURN named after academician V. Lazaryan demonstrates to the use of the modern networking technologies, which changed, improved and expanded the scope of services of the library institution. Conclusions. The research allows conclude to mastering library specialists of new knowledge and working skills to mobile information technologies. The introduction these technologies to practical activity promotes further development of the academic library and helps to improve forms of service for remote users to digital content.

Keywords: academic libraries; networking information technologies; innovative development; digital media; remote user
\end{abstract}

\section{Introduction}

The international movement for openness of information and knowledge, the rapid growth of the number of digital media, the creation of digital libraries require upgrading to the educational infrastructure. Changing the stereotypes of modern library users are helping to transform libraries from simple book collections to media centers. These centers create the conditions for education, science, as well as spaces for collaboration, communication and leisure. This has a positive effect on the socialization and self-realization of the young people studying in the educational institution. Those who wish to get an education increasingly prefer a continuous form of study, namely distance courses. Distance learning courses are based on networking information technology.

These changes will best meet new user needs. It is impossible to imagine a modern university library without the use of the latest media technologies. The authors aim to understand the processes that are taking place at the present stage of development in educational and librarycommunication activities and to explore the impact of digital network technologies on the modernization of university academic institutions.

Today, there are many publications by domestic and foreign scholars on various aspects of the use of remote technologies and the provision of mobile services to users. Namely, T. Markova, I. Glazkova and E. Zaborova (2016) investigated the problem of quality of online distance learning, and N. Yevsyukova and S. Fedyaj (2018) examined the issue of improving the

Creative Commons Attribution 4.0 International https://doi.org/10.15802/unilib/2019_187420
C. V. B. Hovorukha, Larysa A. Semenova, Liudmyla A. Semenova, 2019 110 
skills of library workers through the mass open online courses "Prometheus". L. F. Bandylko (2018) identified tendencies and directions of innovative activity of Ukrainian libraries at the present stage, and V. Zagumenna, T. Granchak (2017) provided an analysis of distance education of librarians in the virtual environment. M. L. Smirnowa, (2017) explored the motivational potential of new media and e-learning programs, and L. W. Afanasjewa with M. L. Smyrnowa, (2019) examined the use of innovative multimedia technologies in foreign language classes by technical students. V. M. Kukharenko's work (2018) is devoted to the obstacles to the implementation of distance learning. Areas of application of modern multimedia and interactive technologies in education are covered in the work of O. Ye. Konovalenko and V. O. Brusentsev (2017), and the issues of the use of modern innovative intellectual technologies in distance learning of engineers in the article by G. A. Samigulina and Z. I. Samigulina (2017). The implementation of networked information technologies in the practical activities of the library to expand and improve the forms and methods of information services for remote users has not been sufficiently researched in scientific publications. This problem was the focus of our research.

\section{Methods}

The current research use analytical and descriptive methods with a focus on analyzing the practical experience of the Scientific and Technical Library of the Dnipro National University of Railway Transport named after Academician V. Lazaryan (STL DNURT) in the field of application of networking information technologies.

The availability of electronic media breaks existing states borders. There are no barriers to knowledge transfer because remote users have now access to scientific and cultural heritage (Brünger-Weilandt, 2014). European libraries have started to create and develop digital online libraries to meet the needs of modern users. For example, the Deutsche Digitale Bibliothek DDB (German Digital Library) is the largest online library in the country. The portal of DDB opens access to culture treasury and sources information for all interested parties. Remote users can read online scientific articles, watch movies, and get acquainted with museum collections to the help of network technologies. It is very important that DDB users can be assured of digitized sources of information, as guaranteed by German cultural and scientific institutions. More than 2000 cultural and scientific institutions, libraries and archives participated in this project. The digitized material in good resolution remains on the website of the institution that worked it. The number of objects in the German Electronic Library is constantly growing. As of the end of 2018, the portal contained records of more than 24 million objects, according to Wikipedia (Deutsche Digitale Bibliothek, (n.d.)). It the long term, this library should integrate all German cultural and scientific institutions to the online libraries and integrate them into the European project "Europeana”.

Ukrainian libraries have already begun to join this global trend, as participation in such projects contributes to the development and popularity of the library, enhances its image. Moreover, the facts show that such projects have great resonance. Thus, in the first few days after launching DDB FIZ portal Karlsruhe recorded 3.6 million hits and more than 25.6 million downloads (Deutsche Digitale Bibliothek - Kultur und Wissen online, 2012, December 20).

Networking information technologies are spread across different spheres of public life because their use for professional development of employees satisfies both the workers themselves of production or business companies, and employers. Modern multimedia and interactive technologies are used for modeling and creation of production situations, "field" researches, psychological exercises, creation of video presentations and videos for advertising of production, etc.

Creative Commons Attribution 4.0 International https://doi.org/10.15802/unilib/2019_187420
C. V. B. Hovorukha, Larysa A. Semenova, Liudmyla A. Semenova, 2019 111 
Integration of knowledge and communication, the international movement for open access to knowledge are changing the functioning and development of academic libraries in the direction of providing high-quality information services to the author-scientist and supporting the philosophy of open access to knowledge. Shifting the vector of priority to the needs of userscientists, providing new digital services to users, participating in the publishing of scientific periodicals turns university libraries into a partner of scientists-educators in the production, preservation and dissemination of knowledge (Kolesnykova, 2017).

Good mastery of the latest technologies, increased access of users to world information resources, production of innovative information products and services, digitization of the most valuable part of funds are the basic directions of development of academic libraries, which requires from library specialists era of networks, electronic documents and virtual reality (Bandilko, 2018).

Media literacy and the use of modern digital technologies make it possible for anyone to achieve their own educational goals, which is why more and more people are opting for distance learning. Distance learning is the main area of application of network technologies. The digital world is transforming education today like no other social phenomenon. Learning is becoming more use virtual as distance learning has some advantages over traditional forms of learning. Distance learning is an effective, flexible, mobile and consumer-friendly training system. By means of distance courses it is possible to receive education of different level or to improve their professional qualification regardless of their place of residence, physical disabilities, to inseparable from their professional activity. Networking technologies provide course participants to webinars, discussion of various issues on the forum or social networking. The process of teaching and certification of students' knowledge is carried out to the help of mobile information technologies.

University libraries should provide information and library support for distance learning systems. The requirements for the technical equipment of library facilities and the professional competence of library specialists are constantly increasing. The application of the latest multimedia technologies requires innovative changes in academic libraries. Functional and constantly updating websites and repositories, an easy-to-use electronic catalog should provide remote users to access to digital textbooks, tutorials, self-study scientific conference materials, as well as educational video films, video presentations, video lectures and virtual exhibitions. Academic librarians must have a good knowledge of the IT culture, constantly improve their level of information culture, in order to help users, work to the electronic catalog, use international databases (DB), evaluate sources of information, publishers, web addresses, values of Internet resources, guidance in the use of bibliographic, thematic, factual references, in different types of citations.

\section{Results and Discussion}

Distance learning courses, participation in the Clarivate Analytics and Bright TALK webinars help prepare professionals for innovative change, and they then actively put their knowledge and skills into practice. For example, in 2014, the employees of the Scientific and Technical Library DNURN named after of Academician V. Lazaryan took the opportunity for distance learning at the courses of NTU "KPI" "Curator of Content 3" (Network Information Analyst) and received certificates after their completion. The training and development of new technologies by STB employees allowed the creation of a new department of library and information technologies in the library with the sector of information analytics and the sector of support of the automated library system and software. The acquired knowledge and skills of

Creative Commons Attribution 4.0 International https://doi.org/10.15802/unilib/2019_187420
C. V. B. Hovorukha, Larysa A. Semenova, Liudmyla A. Semenova, 2019 112 
specialists helped to expand the sphere of virtual services and allowed to fulfill better the information needs of the university community.

Today, librarians carry out scientometric and bibliometric studies prepare analytical management reports, to support the created database "University Science Publication Profile". They also mastered a new type of activity - editorial and publishing activities. This allowed successful publication of the open access electronic journals "Science and the Progress of Transport" (http://stp.diit.edu.ua/) and "Anthropological Measurements of Philosophical Research" (http://ampr.diit.edu.ua/) (Fig. 1).

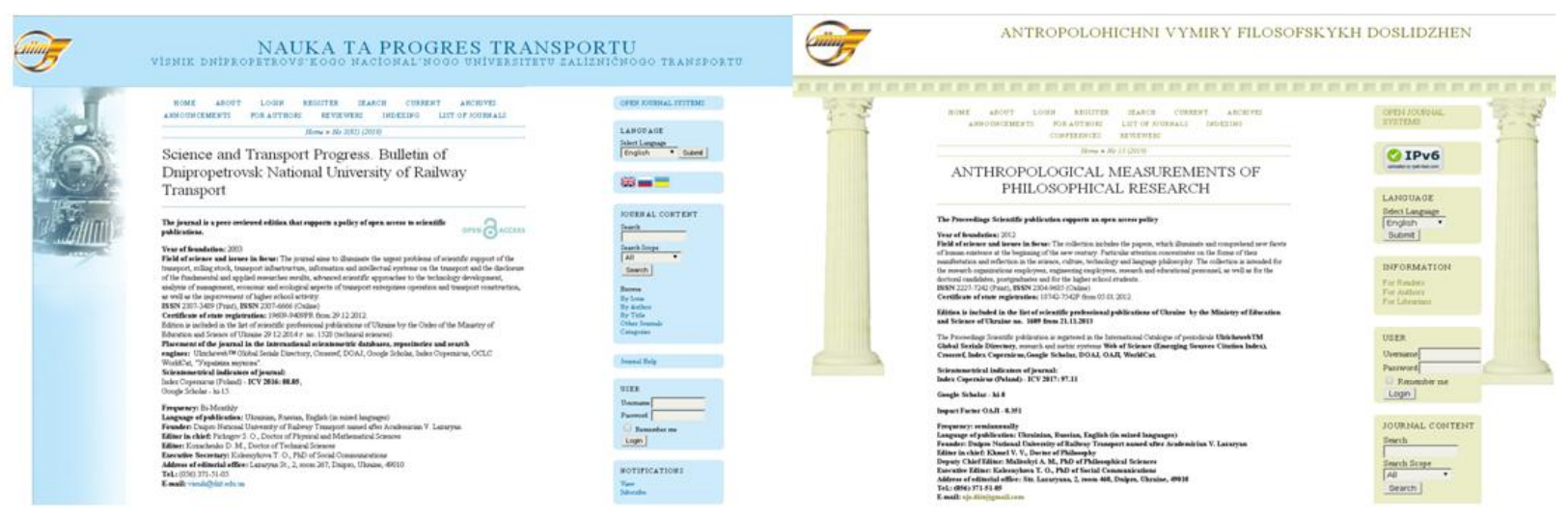

Figure 1. E-Journals of STL DNURT published as "Library Publishing" Project

STB DNURT organizes practical seminars, webinars for the scientific community, creates and places useful and accessible video lessons on the site of the library. These lessons help scientists easily navigate the virtual space. All this has made it possible to expand the scope of online library services in the direction of providing users with access to digital scientific content.

To the help of the Open Conference Systems platform, which has been successfully mastered by the specialists of the institution, the Scientific and Technical Library engages in publishing and promoting the results of scientific activities of the University's scientists through the site of open conferences (Fig. 2).

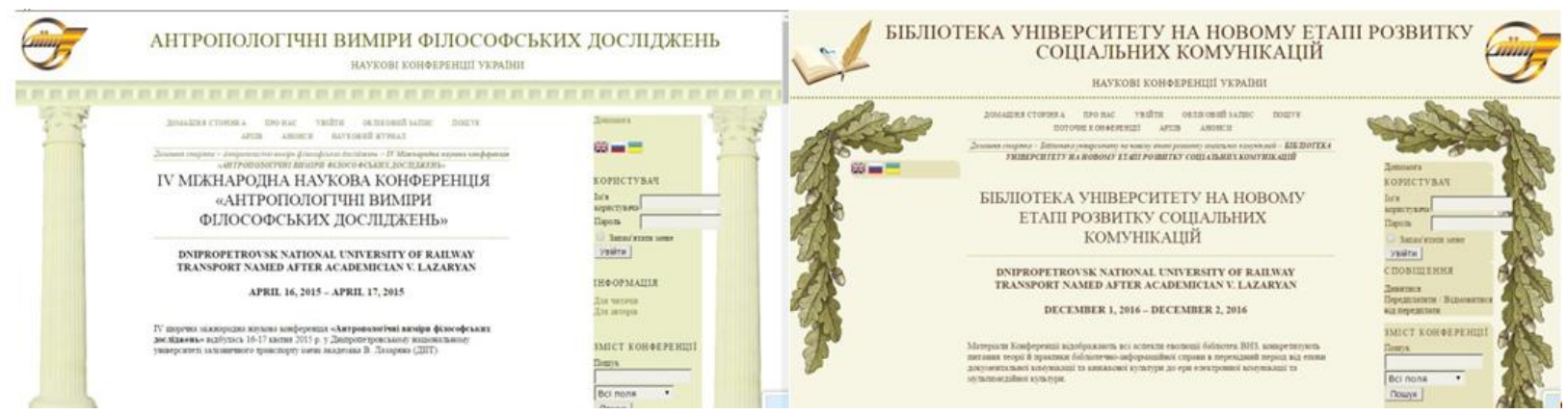

Figure 2. Sites of open scientific conferences supervised by the DNURT Library

In 2014, the first site was created of the scientific conference "Anthropological Measurements of Philosophical Research" (access to the conference: http://confampr.diit.edu.ua/). Prior to the 2016 multi-format scientific and practical conference on library and information affairs in the format of open conferences with live broadcast through the YouTube channel, the site of the second scientific conference "The University Library at a New

Creative Commons Attribution 4.0 International https://doi.org/10.15802/unilib/2019_187420 (c). V. B. Hovorukha, Larysa A. Semenova, Liudmyla A. Semenova, 2019 113 
Stage of Social Communications Development" was created, the materials of which can be viewed at the following link http://conflib.diit.edu.ua/ (Pominova, 2016). All this was done through the use of the latest technologies.

Librarians have mastered all the processes involved in creating electronic copies of print editions (FineReader, Photoshop, ScanTailor, Adobe Acrobat) to join the new workflow that has now spread around the world to digitize the most valuable library stock. To date, collections of " Abstracts of Dissertations"(http://eadnurt.diit.edu.ua/jspui/handle/123456789/39) have been created and placed on the library's website, which contains 542 records, of which approximately 350 contain scanned documents and "Railway ukrainika" on the Rare and Valuable Editions" page (http://ecat.diit.edu.ua/zu/index.html), which gives you access to documents published between 1877 and 1940 and for which copyright has expired (Matveyeva, Yunakovska, 2017).

The coverage of the experience of the Scientific and Technical Library of the DNURT named after Academician V. Lazaryan makes it possible to see to the introduction of mobile technologies activates innovative changes in the activity of the library, makes it necessary to transform information and library activity in the direction of broader satisfaction of remote needs of users.

\section{Conclusions}

Processes of globalization and informatization, accessibility of electronic media, computerization of all spheres of public life, development and improvement of information technologies are leading to innovative changes in various spheres of modern activity of educational and library institutions. Today, online libraries are gaining in popularity, and distance learning is becoming a promising form of educational services today. The use of online information services makes the process of knowledge acquisition more flexible, mobile and convenient for those wishing to acquire knowledge.

The analysis of the practical activity of the Scientific and Technical Library DNURT named after Academician V. Lazaryan confirms the thesis that the introduction of digital network technologies in the activity of the institution modernizes the library, contributes to its popularity among users. So, STB DNURT changed the vector of its activity, expanded the list of services in the field of remote user services. Librarians have mastered new activities (editorial and publishing activities, digitization of valuable sources of library funds, creation of websites of open conferences, scientometric and bibliometric analytics, etc.). Library specialists are able to organize and successfully conduct practical video seminars and conferences, webinars for the scientific community, to help university scientists to navigate well in the scientific virtual space. The Scientific and Technical Library has the potential to continue to actively master these technologies through the development and support of open networking courses, distance training for employees, exchange of experience between educational and library institutions through various activities through multimedia.

The introduction of networked information technology has a positive impact on the innovative development of academic libraries, as it facilitates the transformation of the institution into a modern media center with a wide range of comfortable mobile services for users.

The results of the researches provide a better understanding of current trends in the development of academic libraries, and encourage further research of this topic in the search for new means of improving the field of user service quality content.

Creative Commons Attribution 4.0 International https://doi.org/10.15802/unilib/2019_187420 (c). V. B. Hovorukha, Larysa A. Semenova, Liudmyla A. Semenova, 2019 114 


\section{REFERENCES}

Afanasjewa, L. W., \& Smyrnowa, M. L. (2019). Die Anwendung von Innovativen MultimediaTechnologien beim Fremdsprachenunterricht an der Technischen Universität. Naukovi zapysky Nacionalnogo universytetu "Ostrozka akademiya”, Seriya "Filologiya”, 6 (74), Ostrog, 158-161. doi:https://doi.org/10.25264/2519-2558-2019-6(74) (in German)

Bandylko, L. F. (2018). Informatyzaciya suspilstva ta tendenciyi rozvytku bibliotechnoyi osvity. Zbirnyk materialiv VIII Mizhnarodnoyi naukovo-praktychnoyi konferenciyi Suchasna informacijno-bibliotechna osvita: strategichni oriyentyry, February 27 - March 2, 2018, Kiev, 25-27. Retrieved from https://ula.org.ua/259-publikaciyi/vidannya (in Ukrainian)

Brünger-Weilandt, S. Brauchen wir eine neue Infrastruktur des Wissens? NIG 6.0. Ein Magazin aus Ein Magazin aus gegebenem Anlass, 21-26. Retrieved from http://www.nasig.org/site_page.cfm?pk_association_webpage_menu=310\&pk_associatio n_webpage=9435 (in German)

Deutsche Digitale Bibliothek - Kultur und Wissen online (2012, December 20). Deutschland.de. Retrieved from https://www.deutschland.de/ru/topic/kultura/kommunikacia-smi/nemeckaa-cifrovaabiblioteka-online (in German)

Deutsche Digitale Bibliothek (n.d.). De.Wikipedia.org. Retrieved from https://de.wikipedia.org/wiki/Deutsche_Digitale_Bibliothek (in German)

Kolesnykova, T. (2017). "I Light my Candle from yours...”: Anthropological Aspects of Modern Library Services for Scientists. Anthropological Measurements of Philosophical Research, 11, 49-62. doi: https://doi.org/10.15802/ampr.v0i11.105478

Konovalenko, O. Ye., \& Brusencev, V. O. (2017). Vykorystannya suchasnykh multymedijnykh ta nteraktyvnykh texnologij $v$ osviti. Retrieved from http://repository.kpi.kharkov.ua/handle/KhPI-Press/33606 (in Ukrainian)

Kukharenko, V. M. (2018). Pereshkody vprovadzhennyu dystancijnogo navchannya. Retrieved from http://repository.kpi.kharkov.ua/handle/KhPI-Press/39602 (in Ukrainian)

Markova T., Glazkova I., \& Zaborova E. (2016). Quality Issues of Online Distance Learning. Procedia Social and Behavioral Sciences, 237, 685-691. doi: https://doi.org/10.1016/j.sbspro.2017.02.043

Matveyeva, O. V., \& Yunakovska, V. V. (2017). Obslughovuvannya chytachiv universytetskoyi biblioteky cyfrovym kontentom. Retrieved from http://openarchive.nure.ua/handle/document/3723 (in Ukrainian)

Pominova, O. V., (2016) Mozhlyvosti stvorennya elektronnykh konferencij za dopomogoyu platformy Open Conference Systems: poglyad bibliotekarya. Materialy III mizhnarodnoyi naukovopraktychnoyi konferenciyi The University Library at a New Stage of Social Communications Development,December 1-2, 2016, Dnipro, 253-257. doi: https://dx.doi.org/10.6084/m9.figshare.4479839 (in Ukranian)

Creative Commons Attribution 4.0 International https://doi.org/10.15802/unilib/2019_187420 (c). V. B. Hovorukha, Larysa A. Semenova, Liudmyla A. Semenova, 2019 115 
Samigulina, G. A., \& Samigulina, Z. I. (2017). Distantsionnoe obuchenie inzhenerov na osnove sovremennykh innovatsionnykh intellektualnykh tekhnologiy. Vesnik Natsionalnogo tekhnicheskogo universiteta "Kharkovskiy politekhnicheskiy universitet" (KhPI), Seriya "Informatyka ta modelyuvannya", 21 (1243), Kharkiv, 166-175.doi: https://doi.org/10.20998/2411-0558.2017.21.15 (in Russian)

Smirnowa, M. L. (2017). Neuen Medien und die Motivation im Fremdsprachenunterricht. Retrieved from http://eadnurt.diit.edu.ua/jspui/handle/123456789/10022 (in German)

Yevsyukova, N., \& Fedyaj, S. (2018). Bezperervna systema pidvyshhennya kvalifikaciyi bibliotechnykh pracivnykiv jak odyn iz chynnykiv innovacijnykh zmin u biblioteci. Zbirnyk materialiv VIII Mizhnarodnoyi naukovo-praktychnoyi konferenciyi Suchasna informacijno-bibliotechna osvita: strategichni oriyentyry, February 27 - March 2, 2018, Kiev, 28-33. Retrieved from https://ula.org.ua/259-publikaciyi/vidannya (in Ukrainian)

Zagumenna V., \& Granchak T. (2017). Dystancijna osvita bibliotekariv u virtualnomu seredovyshhi. Visnyk Knyzhkovoi palaty, 6, 45-47. Retrieved from http://nbuv.gov.ua/UJRN/vkp_2017_6_14

ГОВОРУХА В. Б.

Каф.” Обчислювальна математика та математична кібернетика”, Дніпровський національний університет імені Олеся Гончара (Дніпро, Україна), e-mail govorukhavb@gmail.com, ORCID 0000-0002-0936-9272 CЕМЕНОВА Лариса А.

Науково-технічна бібліотека, Дніпровський національний університет залізничного транспорту імені академіка В. Лазаряна (Дніпро, Україна), e-mail loly.sem2964@gmail.com СЕМЕНОВА Людмила А.

Науково-технічна бібліотека, Дніпровський національний університет залізничного транспорту імені академіка В. Лазаряна (Дніпро, Україна), e-mail mila.sem29@gmail.com

\section{МЕРЕЖЕВІ ІНФОРМАЦІЙНІ ТЕХНОЛОГІЇ ЯК ЗАСІБ ІННОВАЦЙНИХ ЗМІН В АКАДЕМІЧНИХ БІБЛІОТЕКАХ}

Мета. У статті передбачено розглянути сучасні світові тенденції, які вимагають від освітньої та бібліотечної інфраструктури суттєвих змін. Розгляд та аналіз цих тенденцій, а також сучасного стану розвитку освітньої та бібліотечної сфери дасть змогу зрозуміти, як упровадження мультимедійних технологій і розширення сфери дистанційних послуг впливає на діяльність академічних закладів. Методика. На сучасному етапі різко зростає популярність дистанційних технологій, бо вони якнайкраще здатні задовольнити нові потреби сучасних користувачів бібліотечних мереж. Автори виявили чинники популярності та сфери застосування цих технологій. а також дослідили, як упровадження інноваційних технологій впливає на різні аспекти діяльності університетських бібліотек. Результати. Висвітлення практичного досвіду роботи Науково-технічної бібліотеки Дніпровського національного університету залізничного транспорту імені академіка В. Лазаряна демонструє. яким чином застосування новітніх технологій змінило, удосконалило та розширило сферу послуг бібліотечного закладу. Висновки. Проведене дослідження дозволяє зробити висновок, що засвоєння бібліотекарями нових знань та навичок роботи 3 дистанційними інформаційними технологіями, а також упровадження їх у практичну діяльність сприяє подальшому розвитку академічної бібліотеки, допомагає поліпшити форми обслуговування віддалених користувачів цифровим контентом.

Ключові слова: академічні бібліотеки; мережеві інформаційні технології; інноваційний розвиток; цифрові носії інформації; віддалені користувачі

Creative Commons Attribution 4.0 International https://doi.org/10.15802/unilib/2019_187420
(C) V. B. Hovorukha, Larysa A. Semenova, Liudmyla A. Semenova, 2019 116 